\title{
電磁駆動フリーピストン式圧縮機のシステム特性に関する研究*
}

\author{
小嶋 英 一**, 品 田 正 昭** \\ 安田敦 紀***
}

\section{System Dynamics of a Solenoid-Operated Free Piston Type of Compressor}

\author{
Eiichi KOJIMA, Masaaki SHINADA and Atsuki YASUDA
}

This report deals with a theoretical and experimental analysis of the system dynamics of a solenoid -operated free piston type of compressor. The test compressor is designed to operate normally at resonant frequencies determined by a spring-mass system consisting of a piston mass, coil spring and gas spring due to the trapped air in the cylinders. Two kinds of mathematical models have been considered in the theoretical analysis: one is "Model A" in which the thermodynamical change in the state of gas in a cylinder is exactly treated with consideration given to the effects of the gas-wall and wall-environmental heat transfer and wall energy storage; the other is "Model B" in which the thermodynamics of gas compression processes in a cylinder is assumed to follow a polytropic change. It is known from a wide range of tests that the heat transfer associated with confining cylinder walls has a great effect on the system dynmaics and that the simulated results of the piston displacement, gas pressure in cylinder, gas temperature in cylinder and cylinder wall temperature from "Model A" are in good agreement with the experimental results within an error around $5 \%$. Furthermore, it has been pointed out that in the case of using "Model B", an appropriate value for the polytropic index should be selected according to the operating conditions.

Key Words: Fluid Power Systems, Pneumatics, Compressor, Piston Cylinder Systems, Gas Compression Processes, Free Piston, Polytropic Change

\section{1. 緒論}

電磁駆動フリーピストン式圧縮機は, 電磁駆動部と 空気圧縮部が一体構造になっているシリンダ内を，ピ ストンだけが電磁力とばねの復元力により電源周波数 $(50 \mathrm{~Hz}$ または $60 \mathrm{~Hz})$ に一致した振動数で往復運動し, 吸・排気弁の作用のもとにポンプ機能を行うものであ る. 従って, 通常の往復式圧縮機のようなモー夕（駆 動部）とピストンを連結するクランクシャフト, コン ロッド，ボールベアリングなどの複雑な動力伝達機構 が不要となり装置が小形・軽量にできる，共振を利用 しているので動力効率が高い, 完全無給油で運転でき るので吐出し空気にオイルミストが含まれない, 機械 的不釣り合い振動が発生しにくいため騒音が低いなど

\footnotetext{
*平成 6 年 4 月 15 日 原稿受付

$* *$ 正員, 神奈川大学工学部

(所在地 干221 横浜市神奈川区六角橋3-27-1)

***神奈川大学大学院（現, 日東工機株式会社）
}

多くの優れた特徴を有している.この特長を生かして, 医療機器, 食品加工機, 液体擋汼機, 浄化槽ブロワ, 空気 軸受, 液・粉体輸送機など広い分野で使用されている。

しかし，この圧縮機ではピストンの運動が機械的に 拘束されていないために，ピストンのストロークは一 定ではなく, 作動条件, シリンダ内空気の熱力学的状 態変化の違い, 吸・排気弁（チェック弁）の動特性な ど多くの因子により著しく変化する，そのため，この 種の圧縮機のシステム特性を正確に把握することは非 常に難しく，ほとんどの設計諸元は経験的および試行 錯誤的に求められているのが現状である.

これらの因子の中, 特に重要でかつ複雑な現象であ るガスの圧縮・膨張過程における熱力学的特性に関し ては, ピストン・シリンダから成るプロトタイプのガ ス圧縮過程を対象にガスの熱力学的状態変化に及ほす シリンダ壁の熱伝達と蓄熱の影響を詳細に解析した研 究1), アキュムレータの減衰性能2),3), 空気圧ノズルフ ラッパ弁の応答性4)など空気圧システム（機器）の特性 に及ほす壁の熱伝達の影響を解析した研究などが報告 
されている。しかし，ガス（流体）ばねによる共振を 利用している供試圧縮機のように，ポンプ作用をする ピストンそのものの運動にこれが直接に影響するよう な機器を対象にした研究は発表されていない.

本研究は, 電磁駆動フリーピストン式圧縮機のシス テム特性を精度よく予測できる設計支援のシミュレー ションプログラムを開発することを目的に, シリンダ 壁とシリンダ内空気との間の熱伝達およびシリンダ壁 の熱蓄積の影響もある程度㛜密に取扱ってシステム特 性を理論解析し, 実験結果と比較検討しながら, 各要 素の理論数学モデルの妥当性と適用限界について検討 を行ったものである。

\section{2. 記号}

本論文で使用する主な記号は以下のとおりである。

$A$ : シリンダの断面積 $\mathrm{m}$

$A_{d}$ : 吐出しチェック弁の有効開口面積 $\mathrm{m}^{2}$

$A_{r}$ :ダンピングオリフィスの有効開口面積 $\mathrm{m}^{2}$

$A_{s}$ : 吸込みチェック弁の有効開口面積 $\mathrm{m}^{2}$

$c$ : ピストンの抵抗係数 $\mathrm{N} \cdot \mathrm{s} / \mathrm{m}$

$C_{p}$ : 空気の定圧比熱 $\mathrm{J} / \mathrm{kgK}$

$C_{v}$ : 空気の定積比熱 $\mathrm{J} / \mathrm{kgK}$

$C_{w}$ : シリンダ壁の比熱 $\mathrm{J} / \mathrm{kgK}$

$f$ : 周波数 $\mathrm{Hz}$

$F(x, I)$ : ピストンに作用する電磁力 $\mathrm{N}$

$h$ : 熱伝達率 $\mathrm{W} / \mathrm{m}^{2} \mathrm{~K}$

$I ： コ イ ル に$ 流れる電流 $\mathrm{A}$

k:コイルばねのばね定数 $\mathrm{N} / \mathrm{m}$

$\dot{M}_{d}$ : 吐出しチェック弁を流れる質量流量 $\mathrm{kg} / \mathrm{s}$

$\dot{M}_{r}$ : ダンピングオリフィスを流れる質量流量 $\mathrm{kg} / \mathrm{s}$

$\dot{M}_{s}$ : 吸込みチェック弁を流れる質量流量 $\mathrm{kg} / \mathrm{s}$

$m:$ ピストンの質量 $\mathrm{kg}$

$n:$ ポリトロープ指数

$P$ : 压力 $\mathrm{Pa}$

$\dot{Q}$ : 単位時間に流れる熱量 (その仕事当量) W

$R:$ 空気のガス定数 $\mathrm{J} / \mathrm{kgK}$

$S:$ 伝熱面積 $\mathrm{m}^{2}$

$t$ : 時間 $\mathrm{s}$

$T$ : 空気の温度 $\mathrm{K}$

$T_{w}:$ 壁の温度 $\mathrm{K}$

$x$ : ピストン変位 $\mathrm{m}$

$x_{c}$ : 吐出しチェック弁ポート孔の位置 (Fig. 2

参照) $\mathrm{m}$

$x_{i}$ : コイルばねの初期ひずみ $\mathrm{m}$

$V$ : 各空気室の空気の体積 $\mathrm{m}^{3}$
$V_{m}$ : 壁の体積 $\mathrm{m}^{3}$

$v$ : ピストン速度 $\mathrm{m} / \mathrm{s}$

$\varkappa$ : 比熱比 $\quad\left(=C_{p} / C_{v}\right)$

$\rho:$ 空気の密度 $\mathrm{kg} / \mathrm{m}^{3}$

$\rho_{w}$ : 壁の密度 $\mathrm{kg} / \mathrm{m}^{3}$

添字

0 ：周井空気に関する量

$d$ : 吐出し室に関する量

$f_{c}$ : フロントシリンダに関する量

fp：フロントシリンダ側のピストン端に関する

量

$r c:$ リアリリンダ関する量

$r p:$ リアシリンダ側のピストン端に関する量

一：時間平均値

\section{3. 供試圧縮機の構造}

供試電磁駆動フリーピストン式圧縮機はメーカの標 準品の一部を試験用に (各検出器を装着できるように) 改造したものであり，その構造の概略と試験のための 検出機の取り付け位置をFig. 1に示す.

作動原理は以下のとおりである.シリコンダイオー ドの整流器でAC100Vの電流を半波整流し, これを固 定鉄心のコイルに流して軟鉄の永久磁石の可動子をも つピストンに間欠的な電磁力を発生させる.コイルに 電流が流れている半周期の間, ピストンは発生する電 磁力により復元ばねに逆らってリアシリンダ側に駆動 され, 吸込みチェック弁を通してフロントシリンダへ の吸気が行われる(吸込み行程). 整流された電流が零 になり電磁力が発生しない残りの半周期の間, ピスト ンは圧縮されたばねの復元力によりフロントシリンダ 側に押し戻され, 吐出しチェック弁を通してフロントシ

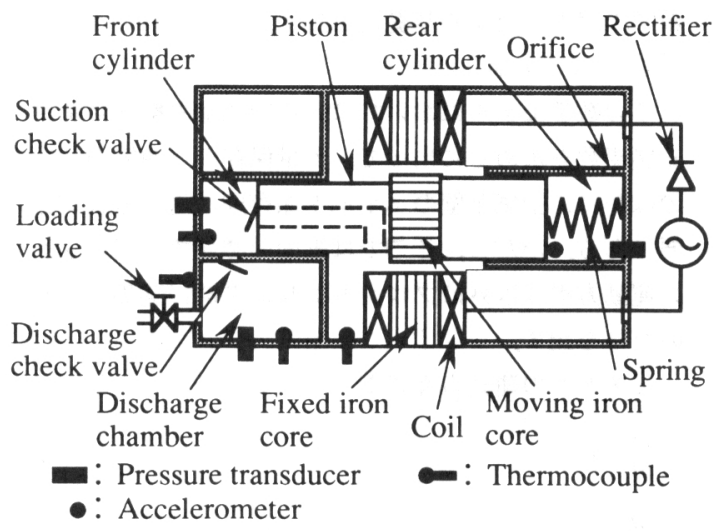

Fig. 1 Schematic of the test compressor and detecting elements for the test 
リンダから吐出し室への排気が行われる(吐出し行程).

フロントシリンダの吸・排気を行う吸込みおよび吐 出しチェック弁には, 開閉の応答性を速く, 漏れを少 く, 圧力損失を小さくするために, 弁自体が復元ばね としても機能する極めて肉厚の薄い平板のシート弁が 用いられている. なお, 吐出しチェック弁の入口ポー ト孔はフロントシリンダの端面より少し離して（供試 圧縮機では, $3.5 \mathrm{~mm}$ ) あられており, ピストンがこれ以 上ストロークするとポート孔を塞いでシリンダ室がクッ ション室を構成し, 吐出し行程においてピストンがフロ ントシリンダの端面に機械的に衝突するのを防いでいる.

供試圧縮機の主な諸元は, ピストン質量 : $0.249 \mathrm{~kg}$, コイルばねのばね定数 $: 8.14 \mathrm{kN} / \mathrm{m}$, フロントシリン ダ側ピストン径 : $30 \mathrm{~mm}$, リアシリンダ側ピストン径 : $34 \mathrm{~mm}$, ピストンの最大ストローク：30mmである.

\section{4. システム特性の理論解析}

\section{1 システム特性に対するカ学モデル}

供試圧縮機は, 復元ばねと電磁駆動部を含むピスト ン部, 吸・排気を行うフロントシリンダ部, 主として 流体ばね機能をもつリアシリンダ部および蓄圧器とし て作用する吐出し室部から構成されており, 電磁コイ ルの電流を入力として作動するものであり, その力学 モデルはFig. 2のように表すことができる.

\section{2 システム特性に対する基礎式}

本研究では, フロントシリンダ室, リアシリンダ室 および吐出し室内の空気の熱力学的状態変化を, 壁と 空気との間の熱伝達および壁の蓄熱に関する理論解析 に基づいて求めた比較的厳密で汎用的な数学モデル (以下, “モデルA”と記す) と, ポリトロープ変化に 従うとした簡単な数学モデル (以下, “モデルB”と記 す）の 2 つの数学モデルについて検討する. 以下, 各 数学モデルに対する基礎式を記す.

[1] “モデルA”

この数学モデルにおいては, 各空気室の空気に関す る諸変数を求めるに当って, 質量保存則（連続の式） のほかに, 空気と壁のエネルギ保存則に対する式が必 要である.ただし，ここでは紙面の関係で, ピストン の運動方程式以外はフロントシリンダ部に関係するも のだけを記す。

ピストンの運動方程式：

$$
\begin{aligned}
\frac{d x}{d t}= & v \\
\frac{d v}{d t}= & \frac{1}{m}\left\{A_{f c} P_{f c}+\left(A_{r c}-A_{f c}\right) P_{0}-A_{r c} P_{r c}\right. \\
& \left.+F(x, I)-c v-k\left(x+x_{i}\right)\right\}
\end{aligned}
$$

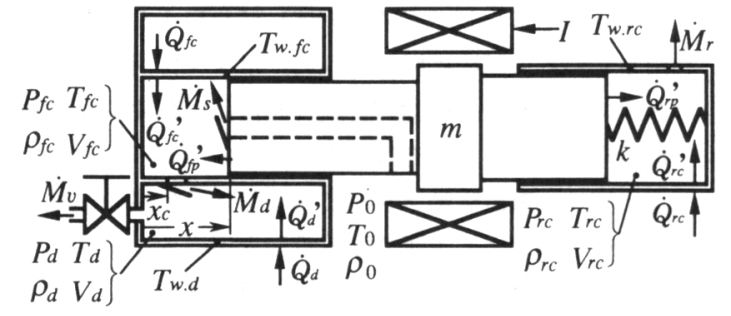

Fig. 2 Physical model for system dynamics of the test compressor

フロントシリンダ内空気に対する質量保存則：

$$
\frac{d \rho_{f c}}{d t}=\frac{1}{V_{f c}}\left(\dot{M}_{s}-\dot{M}_{d}-\rho_{f c} \frac{d V_{f c}}{d t}\right)
$$

ここに

$$
\dot{M}_{s}\left\{\begin{array}{c}
=A_{s} \sqrt{\frac{2 \varkappa}{\varkappa-1} \rho_{0} P_{0}\left\{\left(\frac{P_{f c}}{P_{0}}\right) \frac{2}{\kappa}-\left(\frac{P_{f c}}{P_{0}}\right)^{\frac{\kappa+1}{\kappa}}\right\}} \\
; P_{f c} \geq 0.528 P_{0} \\
=0 \\
A_{s}\left(\frac{2}{\varkappa+1}\right) \frac{1}{\kappa-1} \sqrt{\frac{2 \varkappa}{\varkappa+1} \rho_{0} P_{0}} \\
; P_{f c}<0.528 P_{0} \\
; P_{f c} \geq P_{0}-\Delta P_{s}
\end{array}\right.
$$

$$
\dot{M}_{d}\left\{\begin{array}{c}
=A_{d} \sqrt{\frac{2 \varkappa}{\varkappa-1} \rho_{f c} P_{f c}\left\{\left(\frac{P_{d}}{P_{f c}}\right) \frac{2}{x}-\left(\frac{P_{d}}{P_{f c}}\right) \frac{\kappa+1}{\varkappa}\right\}} \\
; P_{d} \geq 0.528 P_{f c} \\
=0 \\
=A_{d}\left(\frac{2}{\varkappa+1}\right) \frac{1}{\kappa-1} \sqrt{\frac{2 \varkappa}{\varkappa+1} \rho_{f c} P_{f c}} \\
; P_{d}<0.528 P_{f c} \\
; P_{d} \geq P_{f c}-\Delta P_{d}
\end{array}\right.
$$

$$
V_{f c}=V_{f c}(0)+A_{f c} x
$$

ただし， $\Delta P_{s}$ と $\Delta P_{d}$ は吸込みチェック弁と吐出し チェック弁の初期荷重の圧力換算值, $V_{f c}(0)$ は $x=0$ のときのフロントシリンダ内の空気の体積である. フロントシリンダ壁のエネルギ保存則：

$$
\begin{aligned}
& \text { ここに, } \\
& \dot{Q}_{f c}=h_{f c} S_{f c}\left(T_{0}-T_{w . f c}\right) \\
& \dot{Q}_{f c}^{\prime}=h_{f c}^{\prime} S_{f c}^{\prime}\left(T_{w . f c}-T_{f c}\right)
\end{aligned}
$$$$
\frac{d T_{w . f c}}{d t}=\frac{1}{C_{w} \rho_{w} V_{w . f c}}\left\{\dot{Q}_{f c}-\dot{Q}_{f c}^{\prime}+C_{f c}\left(\frac{d x}{d t}\right)^{2}\right\}
$$

ただし, $C_{f c}$ はピストンの粘性抵抗係数 $c$ の中のフロント シリンダ部に対する值(成分), $S_{f c}^{\prime}$ はピストンの位置に よって変るフロントシリンダ内表面積(伝熱面積)である. フロントシリンダ内空気のエネルギ保存則：

$$
\frac{d T_{f c}}{d t}=\frac{1}{\rho_{f c} V_{f c} C_{v}}\left(\dot{Q}_{f c}^{\prime}+\dot{Q}_{f p}^{\prime}+C_{p} \dot{M}_{s} T_{0}-C_{p} \dot{M}_{d} T_{f c}\right.
$$




$$
\left.-P_{f c} \frac{d V_{f c}}{d t}-C_{v} V_{f c} T_{f c} \frac{d \rho_{f c}}{d t}-C_{v} \rho_{f c} T_{f c} \frac{d V_{f c}}{d t}\right)
$$

ここに,

$$
\dot{Q}_{f p}^{\prime}=h_{f p}^{\prime} S_{f p}^{\prime}\left(T_{w . f p}-T_{f c}\right)
$$

状態方程式：

$$
P_{f c}=R_{\rho c} T_{f c}
$$

リアシリンダ部と吐出し室部に関しても式(3)〜式(12) に相当する式が導かれる.

\section{[2] “モデルB”}

この数学モデルにおいては, フロントシリンダ内空 気の熱力学的状態変化を求めるための “モデル A”の 式(3), 式(7)および式(10)に相当する式は, 次の連続の式 （質量保存則）だけとなり

$$
\frac{d P_{f c}}{d t}=\frac{n P_{f c}}{\rho_{f c} V_{f c}}\left(\dot{M}_{s}-\dot{M}_{d}-\rho_{f c} \frac{d V_{f c}}{d t}\right)
$$

密度と温度は, 上で得られた $P_{f c}$ を基に, ポリトロープ 変化の式から次のように求まる。

$$
\begin{aligned}
& \rho_{f c}=\rho_{0}\left(\frac{P_{f c}}{P_{0}}\right)^{\frac{1}{n}} \\
& T_{f c}=T_{0}\left(\frac{P_{f c}}{P_{0}}\right)^{1-\frac{1}{n}}
\end{aligned}
$$

リアシリンダ部と吐出し室部に関しても式(13)〜式(15) に相当する式が導かれる.

\section{3 数値計算法}

本研究では, 実測した電磁コイルの電流 $I$ を力信 号として，4.2 節の常微分方程式群を差分法を用いて 数值計算し, 定常振動状態におけるシステムの諸変数 の時刻歴 (出力信号) を求めた. 各変数の初期値は電 流 $I$ が零の静止状態における値, すなわち, $x=0$, $P_{f c}=P_{r c}=P_{d}=P_{0}$ (大気圧),$T_{f c}=T_{r c}=T_{d}=T_{0}$ (大気 温度 $), \rho_{f c}=\rho_{r c}=\rho_{d}=\rho_{0}\left(=P_{0} / R T_{0}\right)$ とした.ただし， シリンダ壁や吐出し室壁の温度の初期値に関しては, 壁の熱容量がその中の空気の熱容量に比べて大きく, 壁の温度の時間変化が他の変数のそれに比べてかなり 遅いために，すべて実測した定常状態における值（詳 しくは, その時間平均值）を用いた. また, システム 特性に及ぽすピストンの熱蓄積の影響は非常に小さい として, 初めからピストン温度 $\left(T_{w . f p}\right.$ と $\left.T_{w . r p}\right)$ は定常 値の一定值として取扱った. 計算はすべての変数が定 常振動状態になるまで（供試圧縮機においては約 1 秒 後, 換言すれば約50サイクル後まで)行った.計算の刻 みは $0.01 \mathrm{~ms}$ (すなわち,振動の 1 周期の $1 / 2000$ )とした. 計算に使用した主な係数の值は次のとおりである. チェック弁, ダンピングオリフィスおよび負荷弁を通 る流れはすべて断熱流と仮定して
固体壁の間の熱伝達の係数 (熱伝達率) hは, フロント シリンダ, リアシリンダおよび吐出し室の内側では空 気は高速で流れているので $h=290 \mathrm{~W} / \mathrm{m}^{2} \mathrm{~K}$ とし, 外側 では空気は静止しているとして $h=23 \mathrm{~W} / \mathrm{m}^{2} \mathrm{~K}$ とた5). その他の物性値に関しては専門書汭を参考にした。

\section{5. システム特性の実験解析}

\section{1 実験方法と測定系}

圧縮機のシステム特性の測定に先立ち，圧縮機ケー シング各部の温度が熱的に平衡し温度が一定になるま で約10分間のならし運転を行い，その後，いったん圧 縮機の運転を停止して, 各検出器の零点調整を行った。 次いで, 再び圧縮機を起動し, 負荷弁により吐出し圧 力を所定の值に設定し, フロントシリンダ内, リアシ リンダ内および吐出し室内の 3 ヶ所の圧力を半導体圧 力変換器で, ピストン変位を加速度変換器で, フロン トシリンダ室内空気, 吐出し室内空気, 吸込みポート 近傍空気およびシリンダ壁面温度をクロメル・アルメ ル熱電対 (線径 : $13 \mu \mathrm{m}$ ) で, 電磁コイルの入力電流を 試作した電流計で検出し, これらの電圧信号は全てア ナライジングレコーダに同時に取込み記録した。なお， 供試圧縮機では，フロントシリンダとリアシリンダ内 の空気の流体ばね作用も利用して共振を起こさせてい るので, チェック弁やダンピングオリフィスへの連通 を除いては，この室を密閉しなければならず，しかも 容積が限定されているので, ピストン変位の測定に通 常の変位検出器を取付けることができないため, 小形 加速度変換器を用いている. しかし, 加速度変換器の 出力信号は直流分がカットされるため, その信号だけ では振動の中心位置は不明である，そこで本研究では， フロントシリンダ端面にあけた小孔の陌間にグリース を塗布して（密封のため）細い検出棒を挿入し，定常 振動状態時のピストンの上死点の位置を測定した。実 験は, 負荷弁が全開 $\left(\bar{P}_{d} \fallingdotseq 0.1 \mathrm{MPa}, \mathrm{abs}.\right)$ から全閉 $\left(\bar{P}_{d} \fallingdotseq 0.4 \mathrm{MPa}\right.$, abs. $)$ までの間の種々の吐出し圧力の 下で行った。

また，システム特性の測定とは別途の装置を用いて， 理論解析に必要なピストンに作用する電磁力特性を実 測し, 電流 $I$ とピストン変位 $x$ の関数としての実験式 $F$ $(x, I)$ を求めた. Fig. $3 に$, 電流をパラメータとし た電磁力↔変位特性の実測值（変位を増加していくと きと減少させてくるときの平均值）と本研究で使用し た実験式の值をそれぞれ実線と破線で示す。なお電磁 力い変位特性のヒステリシスの量から, クーロン摩擦 に対するスプールの等価粘性抵抗係数 $c$ を求めた（七 ステリシスの量から求まるクーロン摩擦力を $F_{c}$ とし, 
ピストンが振幅 $a$, 周波数 $f$ で調和振動するとすれば, $c=2 F_{c} / \pi f a$ である).

\section{2 実験結果と考察}

負荷弁全開時の入力電流 $I$, ピストン変位 $x$, フロン トシリンダ内圧力 $P_{f c}$, リアシリンダ内圧力 $P_{r c}$, 吐出し 室内圧力 $P_{d}$ およびフロントシリンダ内空気温度 $T_{f c}$ の 時刻歷波形（システム特性）の実測值（実線）と“モ デルA”による計算值（破線）をFig. 4に示す. 図か ら, $x$ に関しては実測値と計算值は極めて良好な一致 を示しているが， $P_{f c}, P_{r c}$ およびT $T_{f c}$ に関してはいずれ も実測值は計算值よりも振幅が小さく, かつ位相が遅 れていることがわかる. 実測值と計算値の間のこれら の関係は他の作動条件に対しても全く同じであった。 以下，最初にこれらの差異の原因について検討する。

先ず, シリンダ内空気温度 $T_{f c}$ に対する両者の差異に 関しては, 本研究では空気温度の測定のために購入で きる市販品の中では最小径 (線径： $13 \mu \mathrm{m}$ ) の熱電対を 使用しているが, それでも $50 \mathrm{~Hz} て ゙$ 変動する空気温度の 測定に対しては感熱部の熱容量が大き過ぎ, 熱電対が 周囲空気の温度変化に正確に応答できないことによる ものと推測される.すなわち, Fig. 4に示す $T_{f c}$ におい ては，極大值において実測值は計算値よりも約 $70^{\circ}$ 位相 が遅れており，もし感熱部が周囲空気の温度変化に対 して一次遅れ特性を示すとし,また $T_{f c}$ の時間変化を50 $\mathrm{Hz}$ の正弦波（実際には正弦波とは異なるが）と仮定す れば，時定数は約 $8 \mathrm{~ms}$ となり，振幅は真值の約 $37 \% に$ 滅少してしまうことになる。この推測の妥当性を確認 するために，付録に示す固体と気体との異相界面間の 熱移動に対する簡単な拡散モデルの式により, 本研究 に使用した熱電対の応答性を理論的に調べた. Fig. 5 に, 周囲の空気温度のステップ変化に対する熱電対の

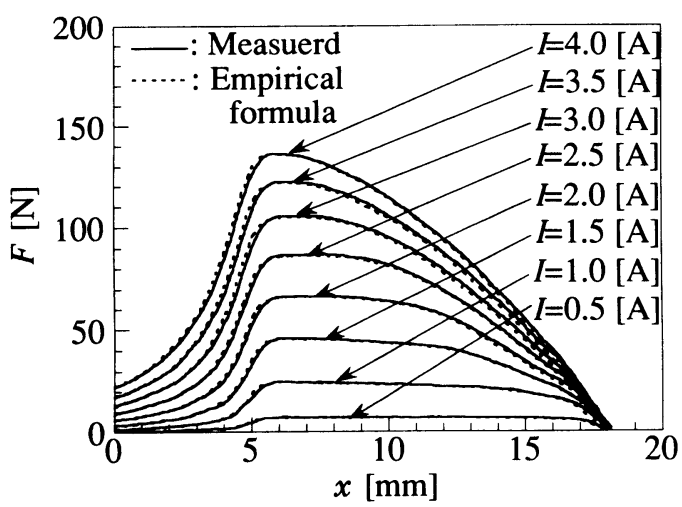

Fig. 3 Measured value of the electromagnetic force (solid line) and its value of empirical formular (dashed line)

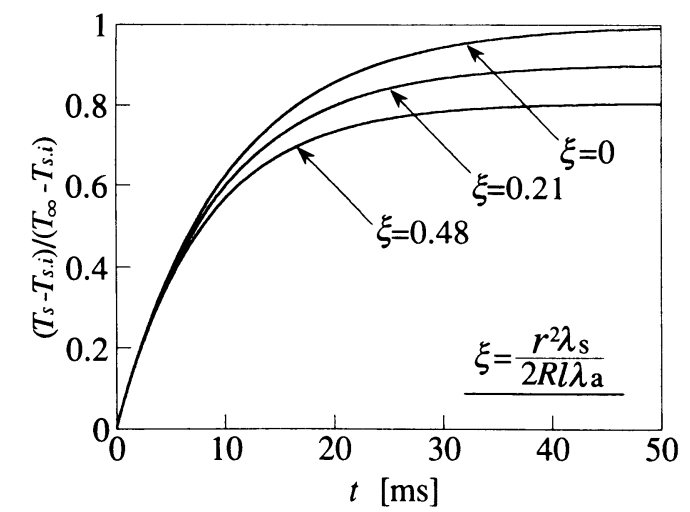

Fig. 5 Simulation result of the temperature response of the thermocouple to a step change of ambient air temperature 
感熱部温度の応答 $\left(T_{s}-T_{s . i}\right) /\left(T_{\infty}-T_{s . i}\right)$ の計算値を 示す.すなわち，本研究に使用した熱電対は一次遅れ 要素に換算して $10 \mathrm{~ms}$ 程度の時定数をもつことが理論 解析からも確認できる.

次に $P_{f c}$ と $P_{r c}$ に対する計算值と実測值の差異に関し ては, 本研究では, 半導体圧力変換器が被測定対象の 空気の温度変化に感応して圧力に対する誤った信号を 出すのを防ぐために, 感圧面 (および圧力測定孔の一 部）に温度絶縁のためのシリコンペーストを塗布して いるため, 感圧面の応答性が悪くなり, 半導体圧力変 換器が周囲空気の圧力変化に正確に応答できないこと によるものと推測される。この場合，シリコンペース 卜部の振動に対する特性を簡単に一次遅れ要素と仮定

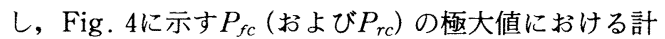
算値と実測值の位相差（約 $17^{\circ}$ ) を基に, 前と同様に時 定数を求めると約 $1 \mathrm{~ms}$ となり, $50 \mathrm{~Hz}$ の調和振動に対 しては振幅は真値の $95 \%$ に減少してしまうことになる.

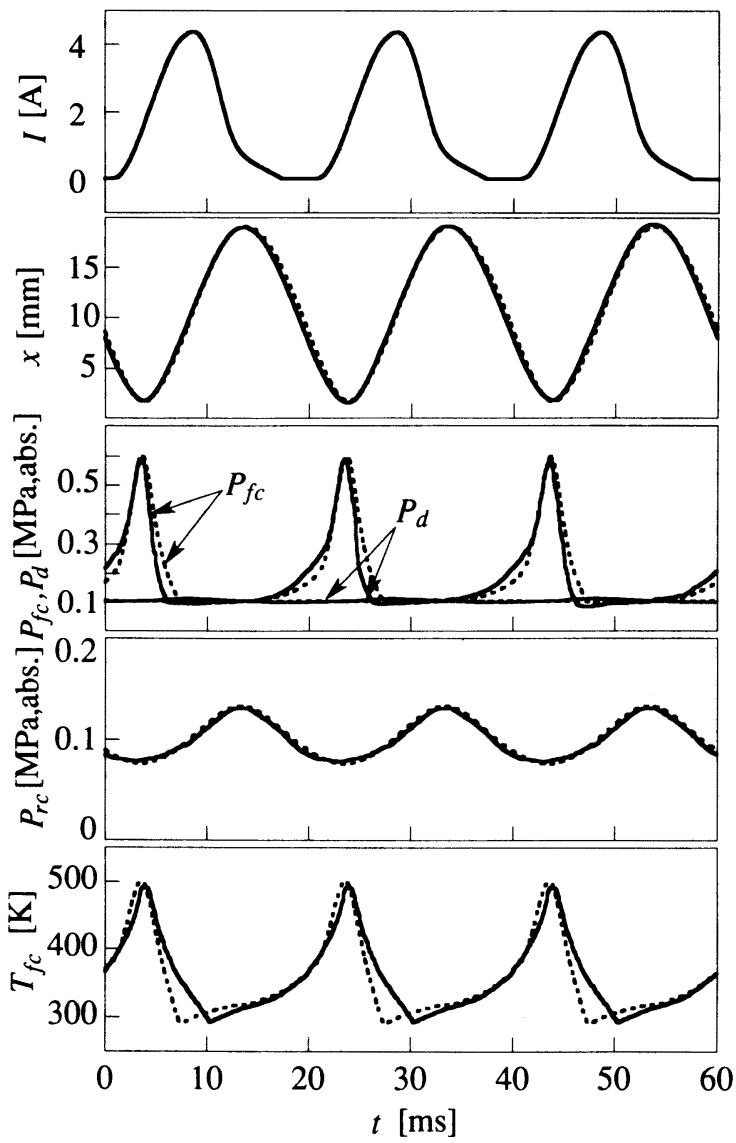

(a) at the loading valve being fully opened
Fig．6(a)，(b)はそれぞれ負荷弁が全開時と全閉時に おけるシステム特性の実測值と“モデル A”による計 算値を比較したものである.ただし, 図中の $T_{f c}, P_{f c} お$ よび $P_{r c}$ の実測値は, 熱電対と半導体圧力変換器が上述 したような一次遅れ特性を示すものと仮定し, 例えば $T_{f c}$ に対しては，実測した $T_{f c}$ の值を基に，

$$
T_{f c}^{*}=T_{f c}+\tau \frac{d T_{f c}}{d t}
$$

から算出した補正した実測値である.ここで, $\tau$ は時定 数を, 上側添字*は補正值を表す. 図から, いずれの 作動条件においても, 前述した $x$ のほかに $P_{f c}, P_{r c} お よ$ び $T_{f c}$ に対しても, “モデルA”による計算值と実測值は良 好な ( $5 \%$ 程度の差異で)一致を示していることがわか る. なお, 負荷弁の他の開度に対しても, 計算值と補正 した実測值がFig. 6程度に一致することを確認している。

Fig. 7(a)，(b)は，それぞれ負荷弁が全開時と全閉時 における“モデル $\mathrm{A}$ ” と“モデル B”によるシステム

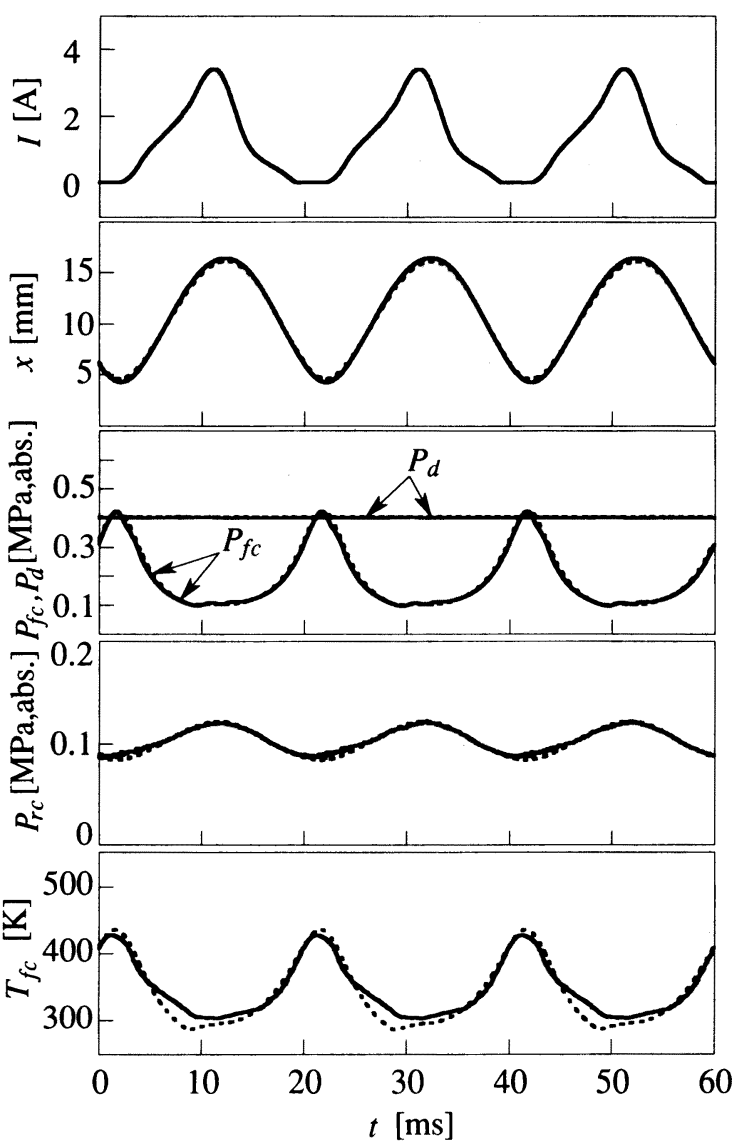

(b) at the loading valve being fully closed

Fig. 6 Comparison of the experimental results (with corrections) with the simulated results from the "Model A" for system dynamics (—: Measured, …... Calculated) 
特性の計算值を比較したものである.ただし, “モデル B”に対しては, シリンダ室内の空気の熱力学的状態 変化に対するポリトロープ指数 $n$ が $n=1$ (等温), $n=$ 1.4 (断熱) およびそれぞれの作動条件に対してピスト ン変位 $x$ とシリンダ内圧力 $P_{f c}$ おび $P_{r c}$ が “モデル A” の計算值に最も近くなる $n$ の值の 3 つの場合の計算値 が示されている.すなわち, 供試圧縮機においては, 負荷弁が全開時には $n=1.30$, 負荷弁が全閉時には $n=$ 1.38 のきに， $x$ と $P_{f c}\left(お よ ひ ゙ P_{r c}\right)$ に対する “モデル B” の計算値は “モデル A” の計算值に（換言すれば, 実測值に）最も近くなる，ただし，“モデルB”におい

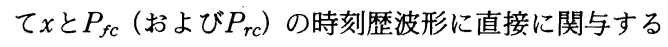
シリンダ内空気の体積弾性係数 $B$ はポリトロープ指数 $n$ のみに依存し(例えば, フロントシリンダ内空気に対 しては, $\left.B=n P_{f c}\right)$, 式(14)および式(15)の密度と空気温度 の基準值 $\rho_{0}$ と $T_{0}$ には依存しないため, $x$ と $P_{f c}$ に対する

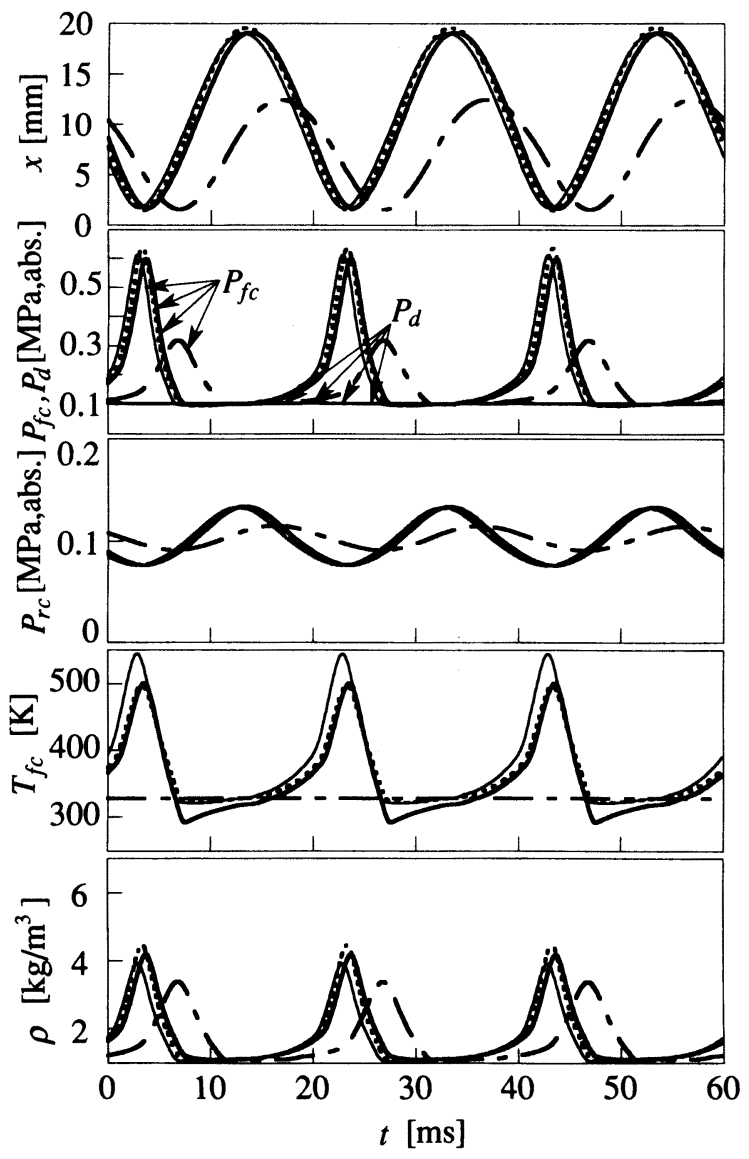

(a) at the loading valve being fully opened $n$ の最適值を用いてシリンダ内空気の温度 $T_{f c}$ や密度 $\rho_{f c}$ の時刻歴波形を定量的に説明できるとはかぎらな い.すなわち, 例えば $T_{f c} に$ 関しては, シリンダ内空気 と周囲壁との間の伝熱量に相当する分だけ, “モデル A”と“モデル B” の計算值には差異が生じる(図 7 (a), (b)の $T_{f c}$ 参照). 以上の考察より, 簡易数学モデル“モ デル B”を用いてシステム特性をシミュレートすると きには, 作動条件に応じた適切なポリトロープ指数 $n$ および空気の温度と密度の基準值 $T_{0}$ と $\rho_{0}$ を選択しなけ ればならないことがわかる。

\section{6. 結論}

本研究は, 電磁駆動フリーピストン式圧縮機の設計 を支援する “システム特性解析用シミュレーションプ ログラム”を開発することを目的に，特にシステム特 性に及洔すシリンダ内空気の圧縮・膨張過程における

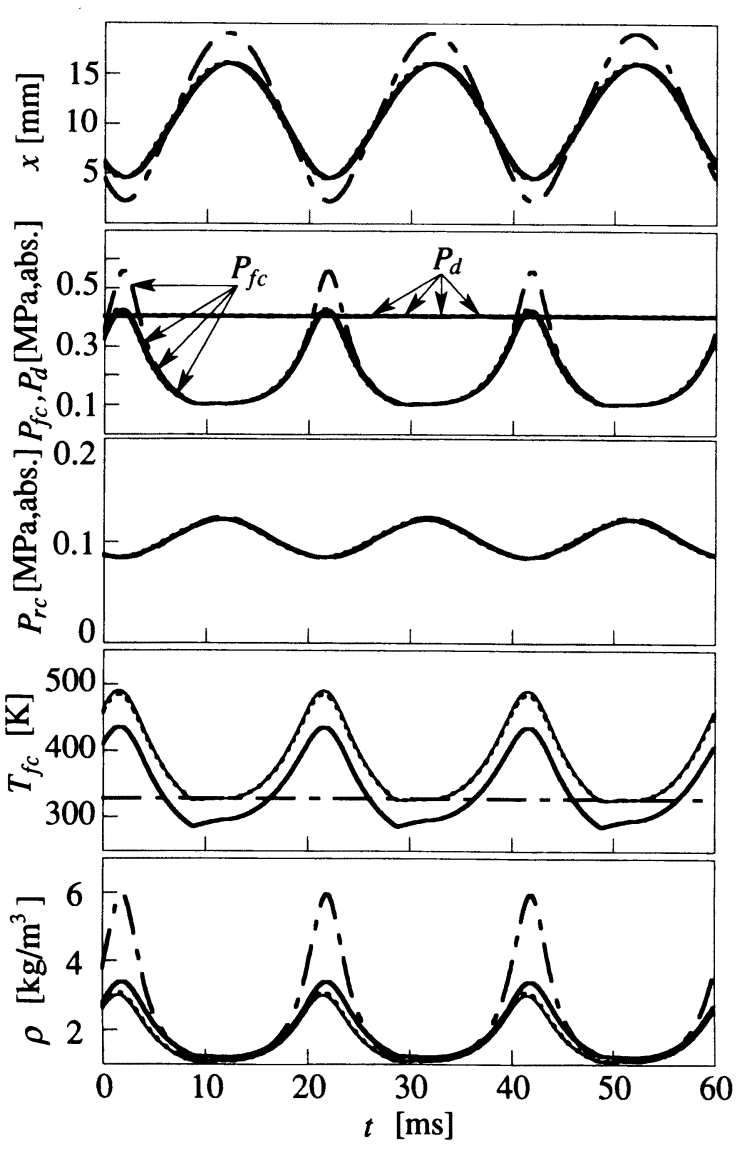

(b) at the loading valve being fully closed

Fig. 7 Comparison between the simulated result from the "Model A" and the "Model B" for system dynamics $[\square$ : Model A, -- : Model B $(n=1.00), \cdots \cdots \cdot$ Model B $\{(\mathrm{a}) ; n=1.30$, (b); $n=1.38\}$, $\longrightarrow$ : Model B $(n=1.40)]$ 
熱力学的状態変化の影響に考察の重点をおいて, 理論 と実験により各構成要素の数学モデルの検討を行った ものである。本研究で得られた主な結論は要約すると 次のようになる.

(1) コイルばねおよびシリンダ（フロントシリンダと リアシリンダ) 内空気の圧縮性に基づく流体ばねと ピストン質量から成るばね・質量系の固有振動数を 電源周波数に一致させて共振状態で駆動するように 設計されているフリーピストン式圧縮機では，機械 系と熱系との連成の度合いが特に大きく, シリンダ 内空気の熱力学的状態変化の違いがシステム特性に 著しく影響を及ぼす。

(2) シリンダ内空気とシリンダ壁との間の熱伝達に関 する理論に基づいて, シリンダ内空気の熱力学的状 態変化をある程度厳密に扱った数学モデルにより, システム特性を広い作動範囲にわたって実用上十分 な精度（各状態変数の実測值に対して約 $5 \%$ 以内の 誤差）でシミュレートできる。

（3）供試圧縮機においては，シリンダ壁の熱容量はシ リンダ内空気の熱容量に比べてはるかに大きいため, 駆動周波数 $(50 \mathrm{~Hz}$ または $60 \mathrm{~Hz})$ 程度の高周波域での システム特性に及ぼすシリンダ壁の蓄熱の影響はほ とんどない. すなわち, シリンダ壁の温度は一定(定 常状態における平均值）として取扱ってよい.

（4）シリンダ内空気の熱力学的状態変化がポリトロー プ変化に従うとした簡易数学モデルによってシステ ム特性を解析する場合には，作動条件に応じた適切 なポリトロープ指数および空気の温度と密度の基準 値を選ばなければならない.

（5）高周波域での空気圧機器のシステム特性に対する 精度の高い実験解析を行うためには, 温度変化に追 従しない圧力検出器と熱伝導に対する時定数の小さ い熱電対 (温度検出器) の開発あるいはこれに対す る適切な補償対策が不可欠である。

最後に, 供試圧縮機の提供と貴重な助言を賜った日 東工器株式会社と, 実験に協力いただいた当時の学生 の伊東宏君と竹島要君に感謝の意を表する。

\section{文献}

1) Paynter, H.M., Fahrenthold, E.P. and Rotz, C.A.: Wall Heat Transfer and Storage Effects on the Thermal Dynamics of Otis-Effect Gas Compression Processes, ASME Journal of Dynamic Systems, Measurement, and Control, Vol. 112 (1990), 728/733.

2 ) Otis, D.R. and Pourmovahed, A.: An Algorithm for Computing Nonflow Gas Processes in
Gas Springs and Hydropneumatic Accumulators, ASME Journal of Dynamic Systems, Measurement, and Control, Vol. 107 (1985), $93 / 96$.

3 ) Otis, D.R.: New Developments in Predicting and Modifying the Performance of Hydraulic Accumulators, Proceedings of the National Conference of Fluid Power, Vol. 28 (1974), $473 / 489$.

4) Kagawa, T.: Heat Transfer Effects on the Frequency Response of a Pneumatic Nozzle Flapper, ASME Journal of Dynamic Systems, Measurement, and Control, Vol. 107 (1985), $332 / 336$.

5 ）例えば, 甲藤: 伝熱概論, 養賢堂 (1987), p. 23 .

6 ) 例えば, 飯田, 他 4 名: 物理定数表, 朝倉書店 (1969). 付

録

温度 $T_{\infty}$ の広い静止流体中におかれている半径 $R$ の 球（固体）と周囲流体との間の熱移動の変化の式は, 対流および輻射の影響が無視できるとすると, 球座標 で次式のように与えられる。

$$
\frac{\partial T}{\partial t}=\frac{\alpha}{r^{2}} \frac{\partial}{\partial r}\left(r^{2} \frac{\partial T}{\partial r}\right)
$$

ここで， $\alpha$ は温度伝導率(温度拡散率とも呼ばれ，流 体の熱伝導率 $\lambda_{a}$ を流体の比熱 $C_{a}$ と密度 $\rho_{a}$ で除した 值： $\left.\lambda_{a} / C_{a} \rho_{a}\right)$ である.

上式を, $r=R て ゙ T=T_{s}$ (固体球の温度), $r=\infty て ゙$ $T=T_{\infty}$ (無限遠の流体の温度)の境界条件で解き, $r=$ $R$ おる温度勾配を求めると次式が得られる.

$$
\left(\frac{\partial T}{\partial r}\right)_{r=R}=\left(T_{\infty}-T_{s}\right)\left(\frac{1}{R}+\frac{1}{\sqrt{\pi \alpha t}}\right)
$$

従って, 測定対象流体（本研究では空気）に接して いる熱電対部を，流体に接している素線の影響も考慮 した等価半径 $R$ の感熱部と長さが $l て ゙$ 半径 $r$ 熱伝導部 （素線部）から成るとし, また, 被覆膜を介してケー シングに接している長さlの素線の他端の温度を一定 ( $T_{s . i}: T_{s}$ の初期值) と仮定すると, 熱電対感熱部の温 度 $T_{s}$ の変化の式が次のように導かれる.

$$
\begin{aligned}
\frac{d T_{s}}{d t}= & \frac{1}{C_{s} M_{s}}\left\{4 \pi R^{2} \lambda_{a}\left(T_{\infty}-T_{s}\right)\left(\frac{1}{R}+\frac{1}{\sqrt{\pi \alpha t}}\right)\right. \\
& \left.-2 \pi r^{2} \lambda_{s} \frac{T_{s}-T_{s . i}}{l}\right\} \ldots \ldots \ldots \ldots \ldots \ldots \ldots \ldots \ldots \ldots \text { (iii) }
\end{aligned}
$$

ただし, $C_{s}$ と $M_{s}$ は感熱部の比熱と質量, $\lambda_{s}$ は素線 (本研 究ではクロメルとアルメル）の平均の熱伝導率である. 